\title{
CARTOGRAFIA GEOGRÁFICA CRÍTICA E O DESENVOLVIMENTO DO “ATLAS DA QUESTÃO AGRÁRIA BRASILEIRA"
}

\section{Eduardo Paulon Girardi ${ }^{1}$}

Resumo: Este artigo aborda a proposta teórico-metodológica de uma Cartografia Geográfica Crítica e sua aplicação no desenvolvimento do Atlas da Questão Agrária Brasileira (www.fct.unesp.br/nera/atlas). O trabalho é parte dos resultados da tese de doutorado defendida em 2008 na Unesp de Presidente Prudente e foi apresentado na mesa $A$ cartografia no contexto socioambiental no II Cartogeo, realizado em 2010 pelo Departamento de Geografia da USP. No artigo apresentamos os fundamentos da proposta da Cartografia Geográfica Crítica e a análise da estrutura fundiária brasileira, um dos vários temas que compõem o Atlas.

Palavras-chave:cartografia geográfica; crítica; atlas; questão agrária.

\section{A critical geographic cartography and the development of the "Brazilian agrarian question atlas"}

\begin{abstract}
This article focuses the theoretical-methodological proposal of a Critical Geographic Cartography and its application in the development of the Atlas of the Brazilian Agrarian Question (www.fct.unesp.br/nera/atlas). The work is parto of the results of the doctoral thesis defended in 2008 at Unesp (UniversidadeEstadualPaulista) and was presented at the panel "Mapping in the socio-environmental context" on the II Cartogeo, conducted in 2010 by the Department of Geography at USP (Universidade de São Paulo). In the paper we present the fundamentals of the Critical Geographic Cartography and the analysis of Brazilian lant tenure structure, one of the many topics that comprise the Atlas.
\end{abstract}

Keywords: geographic cartography; critics; atlas; agrarian question.

\section{INTRODUÇÃO}

A partir do final da década de 1970, com o surgimento da Geografia Crítica, o mapa passou por um processo de marginalização na Geografia brasileira, havendo sinais de um início de reversão deste quadro apenas a partir do final da década de 2000.A marginalização do mapa na Geografia brasileira ocorreu porque a corrente Crítica, ao opor-se ao método e à visão de mundo das correntes Tradicional e Pragmática, também rejeitou as técnicas e procedimentos metodológicos utilizados nas pesquisas dessas duas correntes. A marginalização do mapa na geografia foi fruto de uma crítica radical que, por mais cabida e próspera para o avanço da Geografia brasileira tenha sido,não soube separar os procedimentos metodológicos do método científico evisões de mundo que subsidiavam,

\footnotetext{
${ }^{1}$ Doutor em Geografia. Professor do Departamento de Geografia da Unesp - Campus de Presidente Prudente. E-mail: girardi@fct.unesp.br;
} home page: www.fct.unesp.br/nera/atlas 
problema este para o qual já alertavam na década de 1980 Moraes e Costa (1984, p. 26-30). Por isso, deixou-se de lado grandes avanços nas técnicas de análise de dados e principalmente na cartografia, conseguidas sobretudo pelas correntes Tradicional e Pragmática. O mapa,instrumento metodológico e linguagem por excelência da geografia desde os seus primórdios,perdeu importância por uma interpretação equivocadano movimento de renovação da Geografia.

Essa negligência do mapa pode ser percebida quando analisamos anais de eventos e a revista Terra Livre (até meados da década de 2000), a mais importante da Geografia brasileira. Essas análises demonstram o pequeno espaço que a Cartografia Geográfica ocupa nos debates da Geografia e também a não utilização dos mapas ou sua insuficiência nos estudos geográficos ${ }^{2}$. Contudo, é necessário dizer que a subtração do mapa do discurso geográfico não é uma particularidade da Geografia Crítica no Brasil, pois, como afirma Perkins (2004), a negligência do mapa ocorreu também em outros países onde a Geografia Crítica (marxista, radical) e a Geografia Cultural tiveram grande influência, fazendo com que os geógrafos preterissem o mapa a outras formas de representação do espaço.

Em nossa compreensão, os avanços trazidos pela corrente crítica à Geografia brasileira são muito importantes, porém, no que se refere ao uso do mapa, a Geografia Crítica apresenta deficiências que precisam ser superadas para o seu avanço. É neste sentido, de contribuição para o desenvolvimento da Geografia Crítica, que propomos uma Cartografia Geográfica Crítica (CGC); trata-se de uma crítica construtiva à corrente crítica, e não uma oposição, pois nos consideramos parte desta corrente. Os dois principais objetivos com a CGC são: a) levantar, no interior da Geografia brasileira, a discussão sobre a natureza (crítica) do mapa e sobre a Cartografia Geográfica, e b) incentivar a ampliação do uso do mapa como instrumento de investigação e discurso geográfico e a busca por melhoria na qualidade da produção cartográfica brasileira.

\footnotetext{
2 "Paracontextualizar a Cartografia Geográfica e o mapa na Geografia brasileira analisamos anais de três eventos de Geografia e a revista Terra Livre. O primeiro conjunto de trabalhos analisado foi do XIII Encontro Nacional de Geógrafos, realizado em 2002. Foram publicados nos anais do evento 1.324 trabalhos, dos quais somente $32(2,4 \%)$ são relacionados à Cartografia. A maior parte desses 32 trabalhos tratava de processos de mapeamento e implantação de SIG em estudos de caso. Outro evento analisado foi o VI Congresso Brasileiro de Geógrafos, com 1.335 trabalhos publicados nos anais. Deste total, somente $19(1,4 \%)$ tem relação com a Cartografia e/ou processos de mapeamento. $\mathrm{O}$ terceiro evento analisado foi o VI Encontro Nacional da Anpege, o qual possui em seus anais 453 trabalhos, sendo 11 $(2,4 \%)$ de temas pertinentes à Cartografia. Desses 11 trabalhos, 4 tratam de questões relacionadas aos SIGs. A análise da revista Terra Livre é um referencial importante para medir o uso do mapa na Geografia brasileira, em especial na corrente crítica, pois se trata da mais importante revista de Geografia do Brasil. Para a análise da revista utilizamos os oito números $(14,15,16,17,18,19,20$ e 21) publicados entre 1999 e 2003. Neste período foram publicados na revista 85 artigos, dos quais nenhum referente à Cartografia. Quanto à utilização de mapas nos artigos, em todo o período analisado foram utilizados 39 mapas, os quais estão concentrados nas edições 20 (9 mapas) e 21 (23 mapas). Outro fato que deve ser ressaltado é que os mapas da edição número 21 estão concentrados em apenas três dos 16 artigos nela publicados." (GIRARDI, 2008, p.55-56).
} 
Neste caminho, de forma concomitante com o desenvolvimento da CGC, realizamos uma análise da questão agrária brasileira tendo como principal instrumento metodológico o mapa. É necessário lembrar que a abordagem do campo brasileiro a partir da questão agrária é uma das características da Geografia Crítica, de forma que o desenvolvimento do Atlas da Questão Agrária Brasileira (AQAB) é uma tentativa de demonstrar as potencialidades e, portanto, a necessidade, de utilização do mapa nos estudos críticos, ampliando a capacidade discursiva sobre o espaço e o território. Como os temas analisados no AQAB são vários e há restrição de número de páginas para o presente artigo, analisamos aqui apenas a estrutura fundiária, mesmo que na fala no II Cartogeoà qual este artigo esteja referenciado tenhamos contemplado outros temas. O leitor pode encontrar o Atlas completo no endereço www.fct.unesp.br/nera/atlas . Ao final deste artigo apresentamos o mapa síntese das principais constatações alcançadas com o Atlas.

\section{Uma definição de cartografia geográfica}

Adotamos o par Cartografia de Base e Cartografia Geográfica para designar a diferença entre os conteúdos, técnicas, objetivos e habilidades que compõem a Cartografia que, de modo geral, é de maior interesse dos cartógrafos e aquela de maior interesse dos geógrafos, respectivamente. Obviamente que com esta diferenciação não propomos um aspecto impeditivo/restritivo da transitação dos geógrafos e cartógrafos entre as diferentes técnicas e práticas que configuram a Cartografia de Base e a Cartografia Geográfica. A classificação que apresentamos diz respeito à situação geral em que se manifesta a prática cartográfica na Geografia e na Cartografia. A análise a partir deste par permite compreender melhor o mapa na Geografia e, embora simples, é necessário que expressemos claramente o que entendemos por cada um deles para que nossa proposta seja bem compreendida.

A Cartografia de Base é responsável pela elaboração dos mapas base. Esses são os mapas que envolvem em seu processo de elaboração as técnicas e conhecimentos cartográficos muito específicos, presentes no currículo do engenheiro cartógrafo. Os mapas base são aqueles que fornecem com precisão as informações do terreno. A Cartografia de Base compreende mapas como os topográficos, de navegação (terrestre, aérea e aquática), a elaboração primária de mapas como geológico, pedológico, geomorfológico etc. Em suma, são do seu escopo as atividades de levantamento de informações e mapeamento do terreno 
e de suas características básicas, sejam elas naturais ou obras humanas. A partir dos mapas base são compiladas as bases cartográficas utilizadas na elaboração dos mapas da Cartografia Geográfica.

A Cartografia Geográfica também se interessa pelos mapas da Cartografia de Base, porém, não é do seu escopo a elaboração primária desses mapas. Eles são utilizados pela Cartografia Geográfica como base na elaboração de seus mapas. Os mapas da cartografia geográfica são os mapas geralmente denominados temáticos, os quais possuem como objeto principal um outro tema que não aquele das feições básicas do terreno. Além dos mapas temáticos a cartografia geográfica também engloba os modelos gráficos oriundos da coremática, temática que veremos adiante. De forma geral, a Cartografia Geográfica tem como principal objetivo encontrar as melhores formas de utilização dos mapas para a análise do espaço geográfico. Como a Geografia Urbana ou a Geografia Rural, a Cartografia Geográfica é uma especialidade da Geografia e, do mesmo modo, tem suas preocupações específicas, mas também temas que interessam de forma geral à ciência geográfica. Na Geografia os avanços teóricos, metodológicos e técnicos sobre o mapa são preocupação específica da Cartografia Geográfica, porém, a elaboração e uso do mapa são comuns a toda a Geografia, já que seu objeto de estudo é o espaço geográfico.

A Cartografia Geográfica é a especialidade da Geografia responsável pelo ensino, pesquisa e trabalho com os mapas. Cabe à Cartografia Geográfica ensinar as teorias e práticas de leitura e elaboração de mapas e pesquisar sobre novos métodos e teorias do mapa como instrumento da Geografia. A Cartografia Geográfica é essencial ao desenvolvimento da Geografia por fornecer às outras especialidades desta ciência os subsídios e inovações quanto ao uso do mapa, para o que é salutar manter diálogo com a Cartografia. Nossa elaboração é acerca da "cartografia geográfica crítica" e não apenas "cartografia crítica" porque pensamos o mapa, o processo cartográfico, o uso do mapa, a história da cartografia, a partir das perspectivas da ciência geográfica. Contudo, as elaborações acerca do mapa não se limitam à Geografia e nem são limitadas por ela, já que uma das mais notáveis características do mapa é a interdisciplinaridade, além de ser um forma de linguagem humana muito mais antiga e ampla do que a própria ciência. 


\section{A teoria crítica do mapa}

O primeiro trabalho com grande influência no qual podemos constatar uma visão crítica sobre o mapa é o de Yves Lacoste "A geografia - isso serve, em primeiro lugar, para fazer a guerra" (2003[1985]). As proposições de Lacoste nessa obra, considerada uma das precursoras da Geografia Crítica, evidenciam que o autor assume a relação direta que a Geografia deve manter com o mapa, que é visto por Lacoste como indispensável para pensar e organizar o espaço e a partir de uma crítica ao mapa como instrumento de dominação. Contudo, na contramão desta obra referencial para a corrente crítica, a Geografia Crítica não deu o mesmo peso que Lacoste ao mapa. Sendo assim, de saber estratégico e trunfo para a Geografia na obra de Lacoste, o mapa passa, na Geografia Crítica, a ser considerado uma técnica sem grande relevância para o discurso revolucionário necessário - um equívoco resultado da interpretação errônea que liga o mapa unicamente ao positivismo. Se o mapa como instrumento de dominação era a principal argumentação de Lacoste, a lacuna deixada pelo próprio Lacoste e mais ainda por seus seguidores foi não entender que as mesmas características do mapa que permitem seu uso como instrumento de dominação também podem permitir seu uso como instrumento de libertação. A supressão desta lacuna é possível ao tomarmos como referência a teoria crítica do mapa.

Em 1989 surge o trabalho de John Bryan Harley, o texto "Desconstruindo o mapa”, publicado na revista Cartographyca. Esta obra clássica sobre o mapa é a principal referência do que chamamos aqui de teoria crítica do mapa. Harley (1989) propõe uma leitura da natureza da Cartografia a partir da concepção do mapa como umaconstrução social. Com base principalmente nas obras de Derrida e Foucault, o autor propõe a desconstrução do mapa através da análise de sua textualidade e de sua natureza retórica e metafórica. Harley afirma que as análises conceituais usuais da história da Cartografia se baseavam em fundamentos filosóficos que estabeleciam uma leitura pré-moderna ou então moderna do tema e, por isso, era necessário desenvolver uma análise a partir de fundamentações filosóficas que permitissem uma leitura pós-moderna. Para tanto, Harley afirma que a estratégia de desconstrução é a chave. O autor apresenta a desconstrução como "tática para romper a ligação entre realidade e representação que tem dominado o pensamento cartográfico. [...] o objetivo é sugerir que uma epistemologia alternativa, baseada mais na teoria social do que 
no positivismo científico, é mais apropriada para a história da Cartografia." (p.02, grifo nosso).

Da teoria de Foucault, Harley (1989) utiliza, para o processo de desconstrução do pensamento cartográfico, a ideia da "onipresença do poder em todo o conhecimento, mesmo sendo o poder invisível ou implícito, incluindo o conhecimento particular codificado nos mapas e atlas." Das ideias de Derrida ele toma a presença de retórica em todos os textos, o que "demanda uma busca por metáfora e retórica em mapas nos quais antes os pesquisadores encontravam somente medidas e topografia." (p.03). Neste sentido, o mapa é visto como um texto a partir da compreensão de que "'o que constitui um texto não é a presença de elementos de linguística, mas o ato de construção', sendo assim, os mapas, como 'construções que empregam um sistema de signos convencional', tornam-se textos". (p.07). Os mapas são artefatos culturais.

A Cartografia é conceituada por Harley como "um discurso - um sistema que dispõe de um conjunto de regras para a representação do conhecimento intrínseco às imagens que definimos como mapas e atlas." (p.12). O autor apresenta duas formas de poder na Cartografia: a externa e a interna. Por poder externo ele entende o poder exercido por alguém sobre o mapeamento; não é o poder intrínseco ao mapa e ao mapeador, mas sim o poder que é fruto da demanda do contratante para quem o mapa é elaborado. Já o poder interno é o poder próprio do mapa, exercido a partir da seleção e hierarquização dos elementos representados. (HARLEY, 1989). Podemos concluir que esses dois poderes são indissociáveis, pois só a partir do poder interno é que o poder externo pode existir, já que é o tratamento das técnicas e dos elementos representados que possibilita diversas expressões de um mesmo espaço.

Harley afirma que a proposta de desconstrução do mapa possibilita três análises na história da Cartografia. Primeiro, permite desmitificação da Cartografia e do mapa como objetivos, refletores de uma visão exata da realidade. Segundo, permite a revisão da importância histórica do mapa. Por fim, permite que a história do mapa ganhe espaço na leitura interdisciplinar do texto e do conhecimento. (HARLEY, 1989). Através da estratégia de desconstrução o autor demonstra que os mapas tidos como "científicos" "não são somente produtos das 'regras da geometria e da razão', mas também são produtos de normas e valores da tradição social..."' (p.02). Harley se posiciona, assim, de forma crítica à concepção do mapa como objetivo e inquestionável. Os princípios da desconstrução do mapa 
apresentados por Harley estabelecem uma abordagem crítica do mapa. Após Harley, diversos trabalhos surgiram sobre a temática, sendo necessário citar Monmonier (1991), com o livro "Como mentir com os mapas", Jeremy Black (1997), com "MapsandPolitcs",e o artigo recente de Cramptom e Krygier (2006), "Uma introdução à cartografia crítica". Todos contribuem com Harley na teoria crítica do mapa.

As proposições sobre o caráter discursivo, retórico e subjetivo do mapa não devem ser compreendidos como argumentos para não utilizá-lo, mas, ao contrário, são reforçadores de sua eficácia para a análise baseada na teoria social crítica, já que essas são características doque é científico para além dos estabelecimentos positivistas, como defende a Geografia Crítica. A abordagem crítica do mapa propõe que não é verdadeira a suposta ligação direta e indissociável do mapa com o positivismo, de forma que o mapa não é sua elaboração exclusiva. As características de um mapa dependem do seu autor, pois é ele quem possui um método de investigação e o mapa é mais um instrumento analítico para servi-lo na análise da realidade. O mapa é a representação do mundo segundo a visão do seu autor e, por isso, é uma elaboração útil a todas as correntes teóricas da Geografia. Para a Geografia Crítica, o mapa deve ser compreendido como mais uma forma de discutir e denunciar as desigualdades socioespaciais e as disputas territoriaispara tentar alterá-las. A leitura desconstrucionista do mapa é mais uma justificativa para afirmarmos que o mapa é um instrumento indispensável na elaboração do conhecimento geográfico e permite relacioná-lo diretamente aos fundamentos da Geografia Crítica.

Como fonte de informação, o mapa é diretamente ligado ao poder, que está presente na sua elaboração, posse e leitura/interpretação. Este poder, porém, não deve ser interpretado como o poder dominante, unidirecional. Ele não vem apenas de cima para baixo, do dominante para o dominado; também pode vir de baixo para cima, do dominado para o dominante. Assim, no mapa o poder não é apenas a dominação, mas também a resistência, luta pela emancipação, discurso contracorrente. A elaboração de um mapa não é gratuita, ela se dá a partir de uma demanda, de um objetivo definido por seu autor. A teoria crítica do mapa é um fundamento básico para a Cartografia Geográfica Crítica, pois rompe com a visão que relaciona o mapa diretamente ao positivismo e desmitifica a verdade absoluta, neutralidade que supostamente carrega.

Segundo Vesentini (2001) o questionamento da neutralidade também é um dos princípios da Geografia Crítica, sendo assim, este é um dos pontos de ligação entre esta corrente da 
geografia e a teoria crítica do mapa. A teoria crítica do mapa chama a atenção para a textualidade do mapa, sua subjetividade e retórica. Como produto intelectual, o mapa carrega a intencionalidade do seu autor. Desta forma, a teoria crítica do mapa demonstra que ele é importante a todas as correntes da Geografia e contribui para a valorização do mapa principalmente na corrente crítica da Geografia brasileira, pois permite a compreensão de que o mapa é útil ao discurso e à ação.

\section{As abordagens cartográficas}

Abordagem cartográfica é um conjunto coerente de teoria e metodologia relacionado à representação espacial e que possui características particulares que possibilitam distinguir as representações gráficas do espaço elaboradas a partir de seus fundamentos. Os diferentes mapas que caracterizam cada abordagem são resultantes de compreensões diversas do mapa e do processo cartográfico. As abordagens cartográficas utilizam um repertório básico de técnicas de mapeamento em comum, podendo apresentar outras técnicas específicas, de acordo com as bases teórico-metodológicas particulares a cada uma.

Em nossa proposta da CGC adotamos três abordagens cartográficas: a semiologia gráfica, a visualização cartográfica e a modelização gráfica. Para a CGC, essas três abordagens cartográficas devem ser utilizadas de forma conjunta e complementar para que seja possível o desenvolvimento de um projeto cartográfico que explore de forma mais diversa as potencialidades analíticas e discursivas da Cartografia Geográfica. Vejamos em resumo ${ }^{3}$ algumas das principais características dessas abordagens cartográficas.

A obra "Semiologia Gráfica: os diagramas, as redes e os mapas", escrita por Jacques Bertin em 1962, apresenta os princípios do que ele denominou semiologia gráfica. Nessa obra, o autor centraliza seus esforços na normatização da representação gráfica para o tratamento e comunicação de informações através de três elaborações básicas: as redes, os diagramas e os mapas. A ênfase está em comunicar as informações através de representações gráficas. A semiologia gráfica é a base essencial para o mapeamento porque apresenta as regras para obtenção do melhor resultado na comunicação através do mapa. Por este motivo, as demais abordagens cartográficas estão baseadas na semiologia gráfica, porém avançam em relação à investigação através do mapa e à sua discursividade.

\footnotetext{
${ }^{3}$ Pela restrição de espaço, apresentamos neste artigo apenas uma definição breve de cada uma das abordagens cartográficas para que possamos nos dedicar mais à definição de nossa proposta teórico-metodológica.
} 
A visualização cartográfica consiste em descobrir e gerar novas informações através do mapeamento. Ela é resultado da evolução das técnicas de exploração de informações com o uso do computador no mapeamento, o que permitiu maior agilidade no trabalho com grandes volumes de dados. Segundo MacEachren e Ganter (1990) a visualização cartográfica está inserida no desenvolvimento da exploração de informações através da visualização científica e implica em desenvolver imagens de informações não visíveis anteriormente; descobrir através do imageamento. A visualização não é o resultado de um processo, mas o processo em si. As possibilidades da visualização cartográfica confere ao mapa um outro papel no interior da Geografia. Antes, o mapa estava ligado quase exclusivamente ao armazenamento e comunicação das informações espaciais, hoje, porém, com a visualização cartográfica, ele se tornou um instrumento de pesquisa que não se limita à álgebra de mapas e possibilita novas descobertas, revela padrões, formas, relações e dissimetrias no espaço. Neste contexto, a visualização cartográfica reafirma a necessidade e a potencialidade do mapa na Geografia.

A modelização gráfica ou coremática tem como autor principal Roger Brunet e a referência mais completa está na obra "Le déchiffrementdu monde: théorie et pratique de lagéographie" (BRUNET, 2001 [1990]). A coremática está inserida na ampla proposta de análise geográfica de Brunet, por isso, vai além de uma metodologia para a representação do espaço. A teoria que é inerente à coremática tem relação com todo o conjunto teórico da Geografia. Seu produto final não é o mapa, mas uma análise do espaço subsidiada pelo modelo gráfico - uma representação gráfica bidimensional do espaço.

A coremática tem como propósito analisar os sistemas de forças resultantes da interação entre os diferentes atores na produção do espaço geográfico. Esses sistemas de força - ou sistemas geográficos - produzem as figuras geográficas, que "são expressão de estruturas elementares pelas quais passa o domínio do espaço". (p.195). Segundo Brunet (2001 [1990]), as figuras geográficas são recorrentes e, por isso, ele propõe um conjunto de 28 delas que são chave e compõem a base de um alfabeto geográfico. A essas figuras Brunet dá o nome de corema (chorème), com referência ao radical grego que designa espaço. "Os coremas, enquanto estruturas, são abstrações. [...] não se desenha uma estrutura, mas um modelo." (p.198-9). Com esta frase Brunet explicita a diferença entre coremae modelo. O corema é a abstração que fazemos quando lemos a realidade, é o real que apreendemos e representamos através dos modelos gráficos. O modelo espacial é a representação da visão 
que temos da realidade, do espaço, de seu arranjo, formas, organizações ou estruturas; ele é uma "representação formal de um fenômeno." (p.332). A subjetividade do modelo gráfico é bem expressa por Ferras (1993) "o modelo gráfico propõe uma representação (e não a representação) de uma realidade geográfica" (p.9). Como uma caricatura, o modelo retém somente alguns elementos do real. O espaço geográfico é formado por um conjunto de coremas em composição. Essas composições de coremas são as mais variadas, porém Brunet percebeu que algumas são recorrentes e deu a elas o nome de corotipos (chorotypes).

O que interessa à modelização gráfica não é estabelecer um modelo de espaço, mas sim identificar as suas estruturas e representá-las através de um modelo gráfico; uma forma sucinta que compreenda os fenômenos geográficos estruturais de interesse do autor. A partir das elaborações teóricas e práticas da modelização gráfica, é possível lançar mão de argumentos para explicar o espaço geográfico e, ao mesmo tempo, elaborar questões com base nas configurações verificadas. Além de servir à análise regional, a modelização gráfica é destacadamente um instrumento de comunicação da informação espacial.

A coremática constitui, no contexto do processo cartográfico em que pensamos a CGC, uma das últimas etapas - porém não totalizante nem definitiva - da análise espacial auxiliada pelo mapa - ou representação gráfica do espaço. Embora o resultado final do exercício da modelização gráfica não seja um mapa convencional - o modelo é uma representação gráfica do espaço -, a elaboração dos modelos só é possível a partir da compreensão das estruturais verificadas em conjuntos de mapas anteriormente analisados pelo pesquisador. Para a elaboração dos modelos, é necessário que o autor trabalhe com a semiologia gráfica e a visualização cartográfica. Modelos e mapas não substituem uns aos outros; eles são complementares. Os modelos são formas de representação gráfica do espaço que permitem, de forma mais contundente, a expressão da intencionalidade e da subjetividade do autormapeador, de modo que o modelo gráfico é o instrumento analítico e discursivo que expressa de forma mais enfática a teoria crítica do mapa.

\section{A proposta da cartografia geográfica crítica}

As exposições que apresentamos até aqui acerca da Cartografia Geográfica Crítica conduzem a concepções sobre o mapa e o processo cartográfico diferentes daquelas predominantes na Cartografia Geográfica brasileira. Pensar o mapa de outra forma permite também praticá-lo 
de forma diferente. A CGC tem como base a teoria crítica do mapa e considera a semiologia gráfica, a visualização cartográfica e a modelização gráfica abordagens cartográficas intercomplementares. A CGC compartilha dos fundamentos da Geografia Crítica (VESENTINI, 2001; MORAES e COSTA, 1984), em especial a crítica social e o questionamento da objetividade científica. A CGC foi pensada como contribuição para o desenvolvimento da corrente crítica da Geografia e, para isso, a principal estratégia é a valorização do mapeamento e do mapa através da superação de sua concepção como sinônimo de distância e reflexo objetivo da realidade. Com isso, o mapa, por seu potencial analítico e discursivo, pode tornar o discurso e a prática da Geografia Crítica mais efetivos na produção de um espaço menos desigual.

A CGCcompreende simultaneamente teoria, método e técnica.

Teoria: a CGC tem como principal fundamento teórico a teoria crítica do mapa, cuja base é o trabalho de Harley (1989). Essa leitura do mapa é uma crítica à concepção tradicional, que o vincula exclusivamente ao positivismo. Segundo a interpretação de Harley, o mapeador não é apenas um transcritor do espaço; ele contribui diretamente para sua produção. Ainda em relação à teoria do mapa, a CGC está também baseada nas proposições da semiologia gráfica, da visualização cartográfica e da modelização gráfica. A semiologia gráfica contribui como base para o desenvolvimento das elaborações cartográficas através de suas normas, que definem os procedimentos mais adequados para a comunicação da informação espacial através do mapa. Esta abordagem garante maior eficiência na comunicação dos resultados. A visualização cartográfica fornece os fundamentos para utilizar o mapa como instrumento de exploração dos dados, descoberta de novas informações, padrões, rupturas, simetrias e dissimetrias no espaço geográfico. A visualização cartográfica confere ao mapa ainda mais importância/utilidade na análise espacial e, por isso, é um avanço em relação à semiologia gráfica, porém não a suprime; elas são intercomplementares. A modelizacão gráfica apresenta um conjunto teórico bastante amplo sobre a representação espacial e a natureza da Geografia; ela culmina como um amálgama entre semiologia gráfica e visualização cartográfica, fornecendo contribuições ímpares para representação, análise e discurso sobre o espaço geográfico. A modelização gráfica é um avanço para compreender a importância da representação gráfica do espaço na Geografia. Neste sentido, um ponto importante no qual insistimos na CGC é trazer a modelização gráfica como abordagem cartográfica indispensável para o avanço da teoria crítica do mapa, o que não é considerado na literatura anglo-saxã 
que discute a teoria crítica do mapa. A proposta de interpretação-representaçãointerpretação que a modelização gráfica apresenta influencia na forma do entendimento e prática da cartografia, mesmo nas mais tradicionais, avançando em relação ao mapa sinótico e propondo o mapa-modelo.

Método: o método é o caminho traçado pelo autor-mapeador a partir do uso da teoria e da técnica para o desenvolvimento do processo de mapeamento, análise e discurso através do mapa. De acordo com os objetivos do mapeador, o método inclui a escolha das técnicas, dos dados, do formato dos dados, das formas de representação, dos conceitos, dos elementos a serem representados ou omitidos e do uso que o pesquisador faz do mapa no seu trabalho. O método é como o autor pensa, representa e analisa o espaço, por isso compreende sua intencionalidade. A CGC, como parte do método particular de cada pesquisador, tem como característica, assim como a Geografia Crítica, o questionamento da objetividade científica, a ênfase nos problemas sociais e a promoção de uma cartografia geográfica com preocupações sociais.

Técnica: propomos que, em um uso cuidadoso e mais completo do mapa na análise espacial, seja utilizado, de acordo com a teoria crítica do mapa e de forma intercomplementar, o conjunto de técnicas compreendidas pela semiologia gráfica, visualização cartográfica e modelização gráfica. Para isso, é necessário levar em consideração os estabelecimentos da semiologia gráfica; são indispensáveis as ferramentas da cartomática, de exploração de dados e de sensoriamento remoto, as quais permitem atingir os objetivos da visualização cartográfica; e a elaboração de modelos pode servir como instrumento mais contundente de discurso através da representação gráfica do espaço. As técnicas devem possibilitar que o processo de mapeamento promova descobertas ${ }^{4}$, os mapas e modelos devem portar o discurso do autor-mapeador. A utilização conjunta das três abordagens cartográficas possibilita: a) um resultado final do processo de mapeamento eficiente na comunicação; b) melhor apreensão dos fenômenos espaciais; c) embasamento teórico que permite estabelecer relação direta com as teorias e conceitos geográficos; d) metodologias e técnicas de mapeamento diferentes, porém complementares, o que possibilita representação/análise de um mesmo fenômeno de diversas formas e d) alto grau de transmissão do discurso do autor-mapeador através dos modelos gráficos ou mapa-modelos.

\footnotetext{
${ }^{4}$ Como exemplo de programa de cartomática e exploração de dados citamos o Philcarto, que utilizamos no desenvolvimento de nossas pesquisas (ver apêndices 01 e 02-A em Girardi (2008)). Quanto aos SIGs, temos desenvolvido nossos trabalhos com o auxílio do SPRING. Ambos são programas livres com ótimo desempenho e grande variedade de ferramentas. Obviamente que além desses existem diversos outros, principalmente comerciais como o MapInfo, ArcGIS, Cartes \&Données, dentre tantos outros.
} 
A CGC é crítica por duas razões: a) por adotar a teoria crítica do mapa, que contesta a compreensão positivista tradicional, questionando a objetividade científica do mapa, demonstrando seu potencial analítico e discursivo para a pesquisa crítica na Geografia; e b) como consequência da primeira razão, os estudos desenvolvidos a partir da CGC têm como guia a ênfase nos problemas sociais.

A CGC é uma proposta teórico-metodológica cujo objetivo é indicar formas diferentes das tradicionais de concepção e prática cartográfica. O mapa, como parte indissociável do discurso geográfico, deve ser elaborado e utilizado pelas diversas especialidades da Geografia. Neste sentido, a CGC é uma proposta teórico-metodológica que agrupa um conjunto de teoria, técnica e método que, utilizados conjuntamente com as teorias também críticas das outras especialidades geográficas, possibilitam uma leitura da realidade com auxílio do mapa que é mais próxima dos pressupostos da corrente crítica da geografia.

A prática da CGC só é possível se adotarmos a teoria crítica do mapa, admitindo que o mapa, como fonte de conhecimento, portador de textualidade e retórica, e, portanto, poder, é um território imaterial que, por representar imaterialidade e materialidade, contribui para a formação de territórios por meio da apropriação, influência ou domínio do espaço pelos diversos sujeitos territoriais ${ }^{5}$. Como construções sociais, os mapas são parte do processo de produção do espaço geográfico pelas sociedades. Como geógrafos críticos, devemos atuar na análise e intervenção dos problemas da sociedade, priorizando os grupos oprimidos, tentando explicar a causa das desigualdades e propondo mudanças a partir de um posicionamento crítico claro que faça a Geografia, como ciência social, cumprir seu papel.

Neste contexto, o mapa deve ser constante na prática geográfica para que tenhamos nossos objetivos atingidos, podendo intervir na realidade, reorganizando a estrutura do espaço e a forma como ele é produzido, tornando-a menos exploratória. Para este objetivo, a utilização consciente da suposta objetividade do mapa não pode ser descartada como estratégia da atitude política que cabe ao cientista, neste caso, o geógrafo. Desta forma, a Geografia Crítica poderá utilizar as potencialidades discursivas do mapa como instrumento de libertação, ao contrário da dominação que até então predominava no uso dos mapas.

A proposta da CGC é teórico-metodológica e não técnica. Isso quer dizer que nossa intenção, ao contrário do que muitos leitores podem esperar, não é propor novas técnicas de elaboração cartográfica, mas sim propor uma referência de entendimento e uso críticos do

\footnotetext{
${ }^{5}$ Nossas referencias e proposições sobre o conceito de território (material e imaterial), ações de influência e domínio nos territórios e sujeitos territoriais podem ser lidas em Girardi (2008, p. 35-41).
} 
mapa pela Geografia, encadeando a teoria crítica do mapa e as três abordagens cartográficas mencionadas. Isso não quer dizer que essas três sejam as únicas abordagens cartográficas possíveis existentes, mas sim são as que tomamos para nossa proposta inicial. Também a CGC não suprime as limitações da linguagem cartográfica que, assim como qualquer outra linguagem (falada, escrita, musical etc.) tem seus limites e suas particularidades, que as tornam mais ou menos eficazes para dados usos. Reconhecer as potencialidades e os limites é um outro esclarecimento sobre a cartografia que a CGC pode trazer à negligência do mapa pela Geografia Crítica: a questão não está em criar novas técnicas ou formas de representação para dar conta da complexidade de relações do mundo (capitalista, mas sim utilizar as técnicas já existentes de forma consciente, tomando como referência a teoria crítica do mapa e sobretudo dominando as diversas possibilidades de representação cartográfica, elegendo as mais apropriadas para a análise e elaboração do discurso geográfico. Assim tanto a Geografia quanto a Cartografia Geográfica podem avançar. Foi neste contexto que elaboramos o Atlas da Questão Agrária Brasileira. O próximo tópico deste artigo traz a análise da estrutura fundiária e enfatiza o mapa como instrumento metodológico da pesquisa.

\section{Atlas da questão agrária brasileira: análise da estrutura fundiária}

A terra é sinequa non para a produção agropecuária e a forma como ela é distribuída e apropriada determina as relações que compõem a questão agrária. A condição de ser ou não proprietário da terra influencia nos resultados obtidos por quem produz através dela. $A$ renda da terra, já amplamente analisada por diversos estudiosos da questão agrária, explica bem as consequências da propriedade privada da terra e do direito/concessão de produzir através dela. A renda da terra pode ser pré-capitalista ou capitalista. No primeiro caso, a renda da terra é apropriada através de trabalho, produto ou dinheiro que o proprietário cobra de terceiros pela concessão do direito de produzirem através de suas terras. No segundo caso, da renda da terra capitalista, ela é extraída quando o proprietário se apropria da mais valia dos trabalhadores empregados na produção em suas terras, "ela é a sobra acima do lucro [...] é uma fração da mais valia." (OLIVEIRA, 2007, p.43).

O princípio básico da renda da terra absoluta é a garantia de uma renda excedente acima do lucro médio do capitalista para todos os proprietários de terra, inclusive aqueles que 
possuem terras com as piores características. Esta renda excedente só é possível devido ao monopólio que os proprietários têm sobre a terra. O monopólio permite que os proprietários de terra imponham um preço mínimo à produção, de forma que seja possível que até os proprietários das piores terras consigam obter, além do lucro médio capitalista, a renda da terra. Desta forma, a renda da terra absoluta consiste em um rendimento excedente pago pela sociedade somente pelo fato do proprietário permitir que suas terras sejam colocadas em produção. A partir da renda da terra absoluta é formada a renda da terra diferencial, que aparece em toda produtividade superior à das piores terras. Como o preço mínimo dos produtos são definidos a partir da produtividade das piores terras, quanto mais férteis e melhor localizadas forem as terras, maior será a renda da terra (renda diferencial I) e quanto mais investimentos forem feitos para melhorar a produtividade, também maior será a renda da terra apropriada pelo proprietário (renda diferencial II). Além disso, é possível extrair a renda da terra de monopólio em regiões restritas onde a terra possua características que permitam a produção de produtos com características particulares, produzíveis exclusivamente naquelas regiões.

O mais importante a ser compreendido é que a renda da terra absoluta só existe porque o Estado garante a propriedade privada da terra - o seu monopólio. Isso permite que os proprietários decidam individualmente se a terra é ou não colocada em produção e, para que seja colocada em produção, impõem à sociedade o pagamento, além do lucro médio do capitalista, da renda da terra. A imposição da renda da terra é possível porque a terra é limitada (em quantidade e qualidade) e irreproduzível, ou seja, não se podem produzir novas terras como se constroem novas fábricas de canetas, de calçados ou de carros. Este princípio, no qual se baseiam os proprietários para exigir a renda da terra, é o mesmo princípio que nos permite questioná-la, pois a sobrevivência da humanidade não está determinada pela existência de canetas, de sapatos ou de carros, mas sim à existência de alimentos, produzíveis somente através da terra. Desta forma, a propriedade privada da terra vai contra os interesses básicos da coletividade, pois monopoliza o meio primordial de produção que é a terra e a utiliza para gerar a renda da terra; os interesses individuais se sobrepõem aos interesses coletivos. É isso que torna a produção capitalista, que pressupõe a propriedade privada, inclusive da terra, ainda mais exploratória e socialmente injusta na agropecuária do que na indústria. 
A relação entre o latifúndio, agronegócio e produção capitalista no campo, que adotamos neste trabalho, encontra base também nas colocações de Oliveira (2007). De acordo com o autor, a compra de terra no capitalismo é a compra antecipada de renda da terra e a concentração de terra é característica deste sistema de produção. Quanto mais concentrada for a terra, maior é o poder de extração da mais-valia em forma da renda da terra. Os grandes capitalistas, ao investirem na compra de terra, utilizam-na como reserva de valor para especulação. Oliveria (2007) escreve que a grilagem de terra é “o caminho 'gratuito' do acesso à renda; do acesso ao direito antecipado de obter o pagamento da renda, sem mesmo ter sequer pago para poder auferi-la" e a posse é "o ato de quem não quer pagar a renda ou não aceita a condição de que para produzir tenha que pagá-la." (p.99). Desta forma, podemos concluir que latifúndio e agronegócio, para os quais a concentração da terra é indispensável, compõem a exploração capitalista no campo de duas formas: a) através da especulação e compra antecipada da renda no latifúndio e b) pela apropriação da mais-valia no agronegócio.

A concentração da terra é uma das características do capitalismo no campo e agrava a questão agrária. Assim, se assumirmos que a propriedade coletiva da terra é uma possibilidade muito remota na conjuntura política do país, deve-se pelo menos tentar atenuar a concentração da terra para que, mesmo com a permanência da propriedade privada, o uso da terra seja mais democrático e menos explorador. Além de sobrepor os interesses econômicos individuais aos interesses coletivos, a concentração da terra, seja para especulação ou para a apropriação da renda da terra pela produção capitalista, impede que um grande contingente populacional tenha acesso à terra para viver e produzir. Assim, a distribuição mais igualitária da terra é mais coerente com os interesses coletivos, tanto pela melhoria das condições de vida da população, que teria acesso à terra, quanto pela produção de alimentos de forma socialmente mais adequada. Desta maneira, a concentração fundiária é a base fundamental dos problemas da questão agrária brasileira e por isso capital e campesinato disputam a terra como território e a sua concentração ou distribuição é um indicador da gravidade da questão agrária.

Com base na importância da estrutura fundiária na questão agrária, analisamos a forma como a terra é apropriada e distribuída/concentrada no Brasil. Para nossa análise utilizamos dados do INCRA e do IBGE. Os dados do INCRA foram obtidos através do DATALUTAEstrutura Fundiária, cujas fontes primárias são as Estatísticas Cadastrais de 1992 e 1998 e o 
Cadastro de 2003 do INCRA. Os dados do IBGE são relativos aos Censos Agropecuários de 1996 e de 2006. O INCRA elabora o cadastro dos imóveis rurais através da declaração dos proprietários ou posseiros e por isso comporta o caráter jurídico da estrutura fundiária, de forma que um imóvel pode ser uma propriedade ou uma posse (ver o tópico"posses e grilos"). O IBGE considera, nos censos agropecuários, os estabelecimentos agropecuários definidos como

toda unidade de produção dedicada, total ou parcialmente, a atividades agropecuárias, florestais e aqüícolas, subordinada a uma única administração: a do produtor ou a do administrador. Independente de seu tamanho, de sua forma jurídica ou de sua localização em área urbana ou rural, tendo como objetivo a produção para subsistência e/ou para venda, constituindo-se assim numa unidade recenseável. (IBGE, 2006a, não pag.).

Os dados da estrutura fundiária, em especial aqueles do INCRA, possuem uma dimensão política importante, com a qual devemos ser cuidadosos. O cadastro do INCRA é abastecido com dados de natureza declaratória, não havendo conferências com informações dos cartórios de registro de imóveis, o que indica a fragilidade do sistema. A declaração de uma área superior ou inferior à área real do imóvel pode ter como objetivo a redução de impostos, omissão de terras improdutivas, ampliação de crédito rural e grilagem de terras. Por isso, devemos considerar possíveis desvios principalmente no tamanho da área dos imóveis rurais e subutilização das terras. Esses possíveis desvios nos dados do INCRA não os inutilizam, pois essas práticas ilegais, por mais numerosas que possam ser, não se aplicam à maioria dos detentores. Os dados do IBGE também são declaratórios e não estão totalmente isentos desses possíveis desvios, porém, em virtude de sua finalidade censitária, acreditamos que haja menos interesse dos produtores em fornecer informações falsas.

Iniciamos a análise da estrutura fundiária com o índice de Gini, calculado a partir dos dados do INCRA de 1992, 1998 e 2003. Esses dados indicam quem detém(propriedade e posse)a terra e, por isso, pode extrair a renda da terra. Devemos reconhecer a possibilidade da concentração da terra no Brasil ser ainda maior do que o verificado nos números, pois vários proprietários possuem mais de um imóvel rural e o índice de Gini mede os imóveis e não os proprietários. Em 2003 o índice de Gini para o Brasil era 0,816, o que indica grande concentração, já que quanto mais próximo de um maior é o grau de concentração da terra. A evolução entre 1992 e 2003, de apenas -0,010, confirma que as políticas de reforma agrária do período não tocaram na concentração geral da estrutura fundiária brasileira. 
Em 2003 os municípios com médio/baixo índice de Gini (até 0,500) eram 924 (16,6\% dos 5.565 municípios) e compreendiam seis por cento da área total dos imóveis rurais. A região Sul e o estado de Rondônia concentram grande número desses municípios. Os valores do índice entre 0,501 e 0,800 eram verificados em 4.283 municípios (76,9\%) e compreendiam $83,1 \%$ da área total dos imóveis rurais, de forma que esta classe é predominante no território brasileiro. Por fim, os municípios com grau de concentração acima de 0,800 eram $359(6,4 \%)$ e detinham $10,8 \%$ da área total dos imóveis rurais. O mapa 1, que representa os dados do índice de Gini suavizados considerando dois vizinhos, auxilia na análise da concentração fundiária pelo território e destaca regiões onde o processo tende a ser mais intenso.

\begin{tabular}{|c|c|c|c|c|}
\hline UF & GINI 1992 & GINI 1998 & GINI 2003 & \begin{tabular}{|c|} 
Evolução \\
1992-2003
\end{tabular} \\
\hline Acre & 0,883 & 0,865 & 0,785 & $-0,098$ \\
\hline Alagoas & 0,783 & 0,783 & 0,784 & 0,001 \\
\hline Amapá & 0,842 & 0,775 & 0,585 & $-0,258$ \\
\hline Amazonas & 0,935 & 0,927 & 0,837 & $-0,098$ \\
\hline Bahia & 0,802 & 0,826 & 0,807 & 0,004 \\
\hline Ceará & 0,684 & 0,695 & 0,691 & 0,007 \\
\hline Espírito Santo & 0,615 & 0,632 & 0,626 & 0,012 \\
\hline Goiás & 0,717 & 0,720 & 0,720 & 0,002 \\
\hline Maranhão & 0,740 & 0,759 & 0,719 & $-0,021$ \\
\hline Minas Gerais & 0,745 & 0,754 & 0,741 & $-0,004$ \\
\hline Mato Grosso do Sul & 0,807 & 0,806 & 0,805 & $-0,001$ \\
\hline Mato Grosso & 0,813 & 0,803 & 0,763 & $-0,050$ \\
\hline Pará & 0,888 & 0,885 & 0,823 & $-0,065$ \\
\hline Paraíba & 0,753 & 0,758 & $\begin{array}{l}0,755 \\
0,75\end{array}$ & 0,002 \\
\hline Pernambuco & 0,757 & 0,756 & 0,742 & $-0,015$ \\
\hline Piauí & 0,743 & 0,767 & 0,755 & 0,012 \\
\hline Paraná & 0,693 & 0,702 & 0,677 & $-0,016$ \\
\hline Rio de Janeiro & 0,728 & 0,742 & 0,738 & 0,010 \\
\hline Rio Grande do Norte & 0,739 & 0,759 & 0,752 & 0,013 \\
\hline Rondônia & 0,631 & 0,631 & 0,567 & $-0,065$ \\
\hline Roraima & 0,870 & 0,789 & 0,597 & $-0,273$ \\
\hline Rio Grande do Sul & 0,713 & 0,718 & 0,693 & $-0,021$ \\
\hline Santa Catarina & 0,625 & 0,632 & 0,607 & $-0,018$ \\
\hline Sergipe & 0,788 & 0,788 & 0,773 & $-0,014$ \\
\hline São Paulo & 0,750 & 0,754 & 0,744 & $-0,006$ \\
\hline Tocantins & 0,661 & 0,685 & 0,678 & 0,017 \\
\hline Distrito Federal & 0,781 & 0,804 & 0,827 & 0,046 \\
\hline BRASIL & 0,826 & 0,838 & 0,816 & $-0,010$ \\
\hline $\begin{array}{l}\text { Dados: DATALUTA- } \\
\text { Cálculo: Eduardo Pa }\end{array}$ & $\begin{array}{l}\text { rutura Func } \\
\text { n Girardi }\end{array}$ & Cada & do INCRA & \\
\hline
\end{tabular}

A tabela 2 apresenta os dados da estrutura fundiária em 1992, 1998 e 2003. Em 2003 os imóveis pequenos (menos de 200 ha) representavam 92,56\% do número total de imóveis e apenas $28,42 \%$ da área total, perfazendo uma área média de 30 ha. Ao contrário, os imóveis médios e grandes (200 ha e mais) correspondiam a 7,44\% dos imóveis e $71,57 \%$ da área total, resultando em uma área média de 938 ha. Esta distribuição desigual, que corrobora com os resultados do índice de Gini para evidenciar a concentração fundiária no Brasil, também pode ser verificada nos anos de 1992 e 1998. 
Para o mapeamento da estrutura fundiária, utilizamos principalmente os dados da área, pois, se tomarmos o número de imóveis, os menores serão sempre mais numerosos. O que importa realmente é a proporção da área total que cada classe de área detém; é isso que determina o maior ou menor território da agricultura camponesa ou da agricultura capitalista. No mapa 2 os municípios foram classificados segundo a predominância dos imóveis pequenos, médios e grandes na detenção da área total dos imóveis rurais no município. A constatação é que a estrutura fundiária possui uma ordem regional bem definida, com a formação de regiões contínuas. São destacadas regiões no Sul, Sudeste, Nordeste e no norte amazônico em que a área dos menores imóveis é predominante; a região central, onde predomina a área dos imóveis médios, e a região que compreende parte do Centro-Oeste, Norte e o oeste da região Nordeste, onde as terras encontram-se principalmente sob domínio dos grandes imóveis.

\section{Mapa 1}

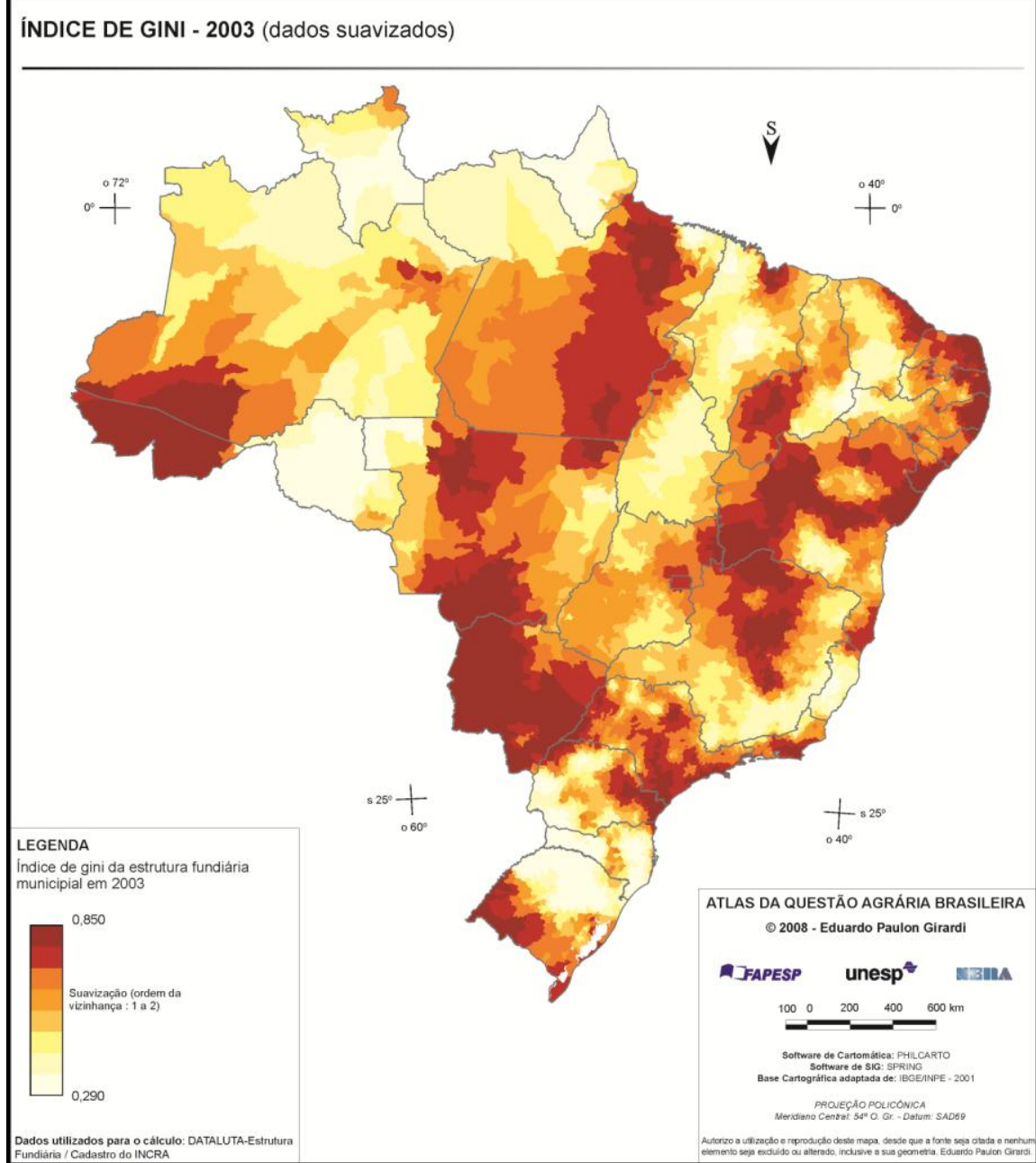

Veja a versão em alta resolução em www.fct.unesp.br/nera/atlas 


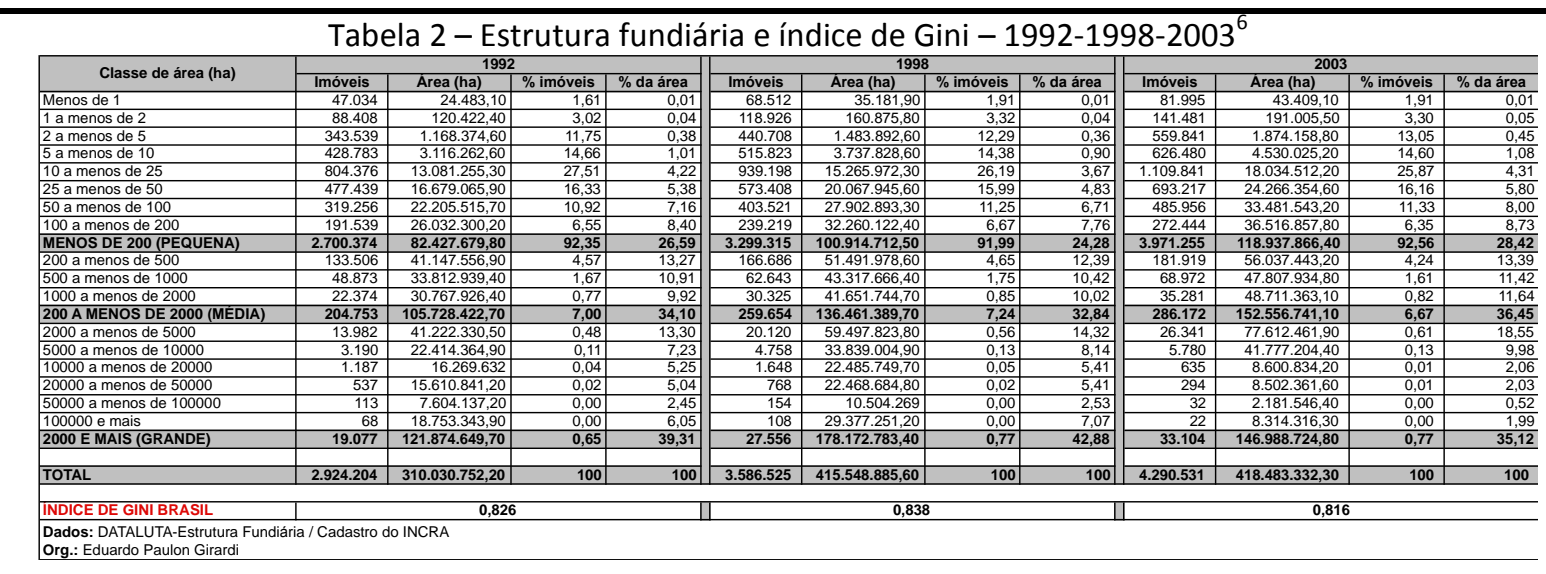

Apesar de não ter havido diminuição significativa do grau de concentração da terra no Brasil entre 1992 e 2003, neste intervalo de onze anos analisado o número de imóveis rurais e a área total dos imóveis apresentou taxas muito elevadas de crescimento. O número de imóveis rurais saltou de 2.924.204, em 1992, para 4.290.531, em 2003 (acréscimo de 46,7\%). Isso seria salutar para a desconcentração fundiária, não fosse o fato de que a área total dos imóveis no mesmo período saltou de 310.030 .752 ha para 418.483 .332 ha (acréscimo de 35\%). Entre 1992 e 2003 o território camponês (imóveis de menos de 200 ha) se territorializou sobre $36.510 .186,6$ ha e o território do latifúndio e agronegócio (imóveis com 200 ha ou mais), sobre uma área duas vezes maior, com 71.942.393,5 ha. Enquanto a evolução 1992-2003 no campesinato perfaz uma área média de 30 ha, a evolução no latifúndio e agronegócio tem área média de 753 ha por imóvel rural. Isso indica, mas uma vez, a disparidade entre esses dois territórios e que a concentração da terra se mantém intocada, apesar do acréscimo de mais de 108 milhões de hectares na estrutura fundiária brasileira. O mapa 3 mostra onde foram acrescidas novas áreas na estrutura fundiária entre 1992 e 2003. O Centro-Oeste e o Norte são as regiões responsáveis pela maior incorporação de novas terras na estrutura fundiária e as microrregiões de Itaituba e Altamira, no Pará, são as que compreendem, individualmente, a maior proporção da área total incorporada na estrutura fundiária brasileira no período 1992-2003.

\footnotetext{
${ }^{6}$ Em 2011 o Cadastro do INCRA registrava no Brasil 5.356.425 imóveis rurais com área total de 590.716.875,34 hectares.
} 


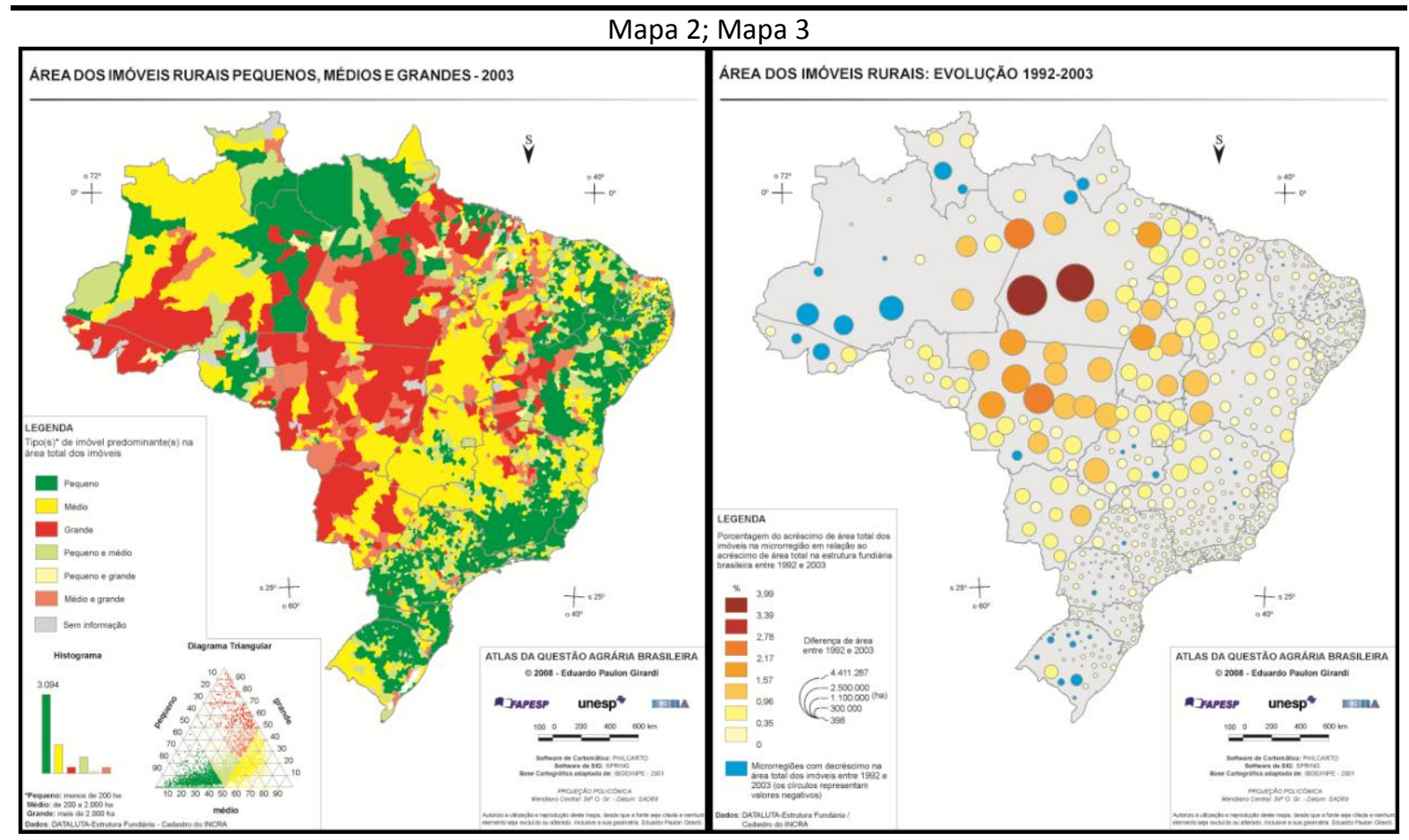

Veja a versão em alta resolução em www.fct.unesp.br/nera/atlas

O INCRA, nos dados do Cadastro Rural, designa como posse os imóveis rurais sem registro legal, independente do seu tamanho. As posses têm grande representatividade na estrutura fundiária brasileira. Elas podem estar em terras públicas, devolutas ou, em casos mais raros, em terras privadas. Por ser prática ilegal, há grande possibilidade do fenômeno ser superior ao alcançado pelos dados do INCRA. De acordo com o Instituto, em 2003 existiam no Brasil $1.172 .980^{7}$ imóveis de posse (27,3\% do total de imóveis rurais do Brasil), os quais perfaziam $66.285 .346,8$ ha $(15,8 \%$ da área total dos imóveis rurais brasileiros). Os detentores desses imóveis eram exclusivamente posseiros e não possuíam nenhum outro imóvel sob condição de proprietário. Porém, além desses detentores que eram exclusivamente posseiros, o cadastro do INCRA também apresenta os dados sobre posseiros que também eram proprietários. No cadastro, as posses e propriedades desses detentores não são discriminadas, de forma que os dados são disponibilizados conjuntamente (somados). Sendo assim, em 2003 os proprietários que também eram posseiros detinham, entre propriedades e posses, 117.909 imóveis rurais e 15.529 .980 ha. Para as análises realizadas doravante, não utilizaremos os dados referentes aos proprietários que também são posseiros e consideraremos apenas os dados dos imóveis de posse.

Na Amazônia Legal, em 2003, as áreas de posses totalizavam 35.027.088 ha, o que correspondia a $19,8 \%$ da área total dos imóveis da região e $52,8 \%$ da área total dos imóveis

\footnotetext{
${ }^{7}$ Para 2010 os dados de número de imóveis de posse e a área desses imóveis permanecia a mesma aqui apresentada.
} 
de posse do Brasil. Tomando dados apresentados por Oliveira (2008), em 2003 o INCRA detinha na Amazônia Legal, 67.823.810 ha, ainda sem destinação. Desta forma, as terras do INCRA na Amazônia Legal somam quase o dobro da superfície sob domínio de posseiros na região. Como mostra o mapa 4, no Brasil as áreas de posse concentram-se na metade norte do país. As posses também são notáveis, de forma menos intensa, na faixa costeira do Sudeste. A representatividade das posses na área total dos imóveis rurais é particularmente importante na região Norte, onde as altas proporções de área de posse nos municípios indicam a constante incorporação de novas terras, característica da frente pioneira da fronteira agropecuária. No Nordeste, especialmente no norte baiano e no leste pernambucano, também são importantes as áreas de posse, mas, neste caso, devido a motivos como a impossibilidade dos pequenos proprietários regularizarem a situação jurídica de suas terras por falta de recursos. O mapa 5 fornece informações sobre a participação dos três grandes grupos de imóveis rurais (pequeno, médio e grande) na detenção das áreas de posse. Na maior parte dos municípios as áreas das posses predominam nos pequenos imóveis (menos de 200 ha). Já nos municípios com as maiores somas de áreas de posse, elas predominam nos imóveis médios e grandes (200 ha e mais), sendo esses casos importantes no oeste da Bahia, sul do Piauí, leste do Tocantins, Mato Grosso e Pará. Com relação às posses no Brasil, é necessário dizer que o Governo Federal, através da MP 458, aprovada no Senado e na Câmara dos Deputados e que deu origem ao programa Terra Legal do INCRA, irá legalizar 67,4 milhões de hectares de posses de até 1.500 hectares na Amazônia Legal, o que é, na verdade, uma medida pró-ocupação da Amazônia pelo grilo, exceto na legalização de pequenas posses - as terras camponesas. 


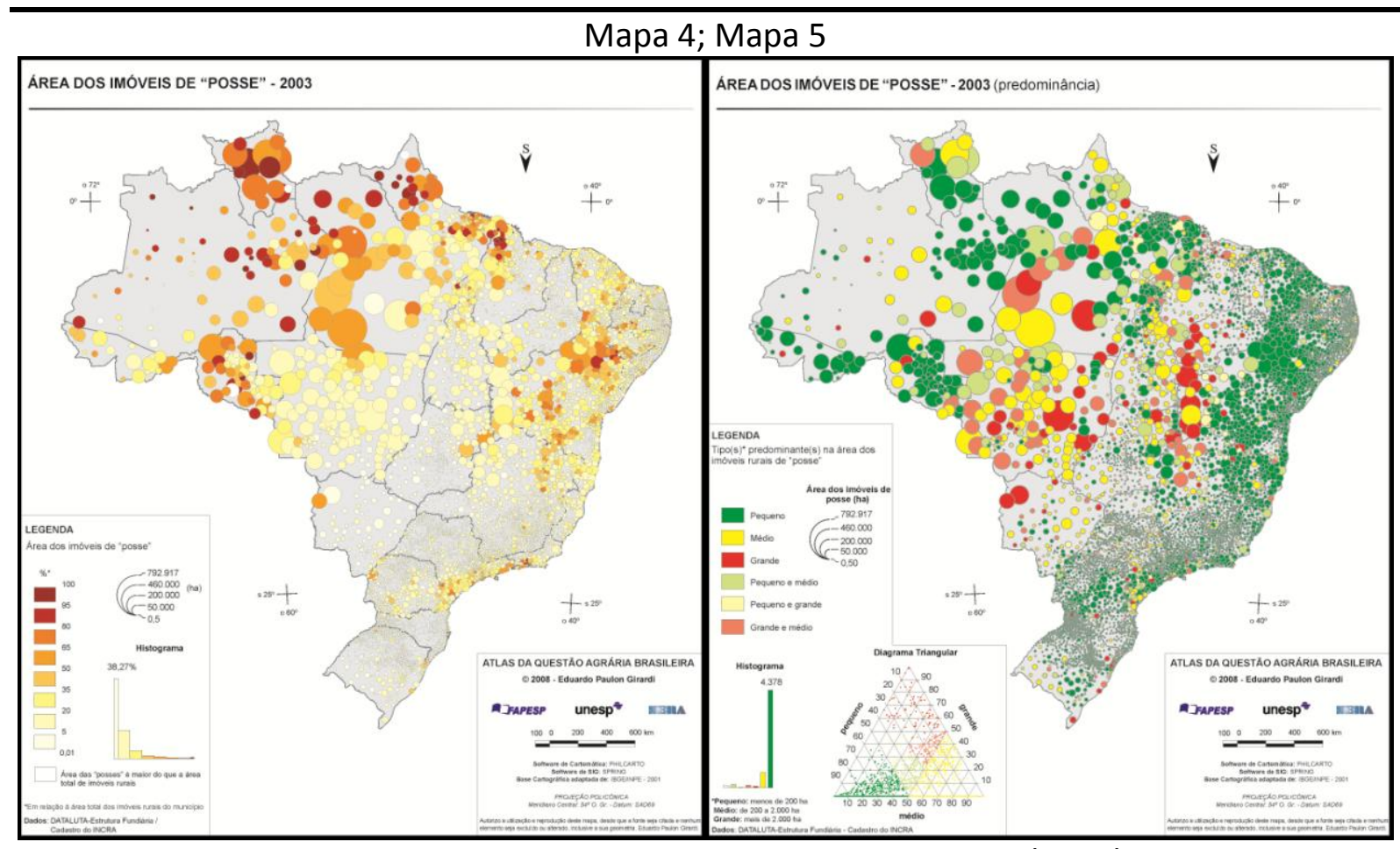

Veja a versão em alta resolução em www.fct.unesp.br/nera/atlas

Os dados do INCRA mostram que em 1998 cerca de 75,4 milhões de hectares de terras exploráveis $^{8}$ não eram exploradas, o que correspondia a $23 \%$ da área total explorável do Brasil. Territorialmente as terras exploráveis não exploradas estavam assim distribuídas: $45,6 \%$ na região Norte, $24,2 \%$ no Nordeste, $26,1 \%$ no Centro-Oeste, $2,2 \%$ no Sudeste e $1,9 \%$ no Sul. O mapa 6 representa o fenômeno de forma detalhada e evidencia a oposição norte/sul. Amazônia Legal, oeste Baiano e Piauí concentravam grande parte das terras exploráveis não exploradas em 1998. A maior proporção de terras exploráveis não exploradas estava nos imóveis grandes, grupo no qual 35,6\% da área total explorável não era explorada. Ainda, se somarmos os imóveis médios e grandes, a área explorável não explorada em 1998 era de 58.738.981,1 ha, ou seja, 77,9\% de toda terra explorável não explorada no Brasil. O mapa 7 representa os municípios segundo a predominância dos imóveis grandes, médios ou pequenos na área total explorável não explorada em 1998. Na Amazônia Legal predominam as áreas exploráveis não exploradas nos grandes imóveis, assim como no oeste da Bahia e do Piauí.

\footnotetext{
${ }^{8}$ Terras que se encontravam, na data do levantamento dos dados, em condições de produção imediata. As terras com matas são consideradas inexploráveis.
} 


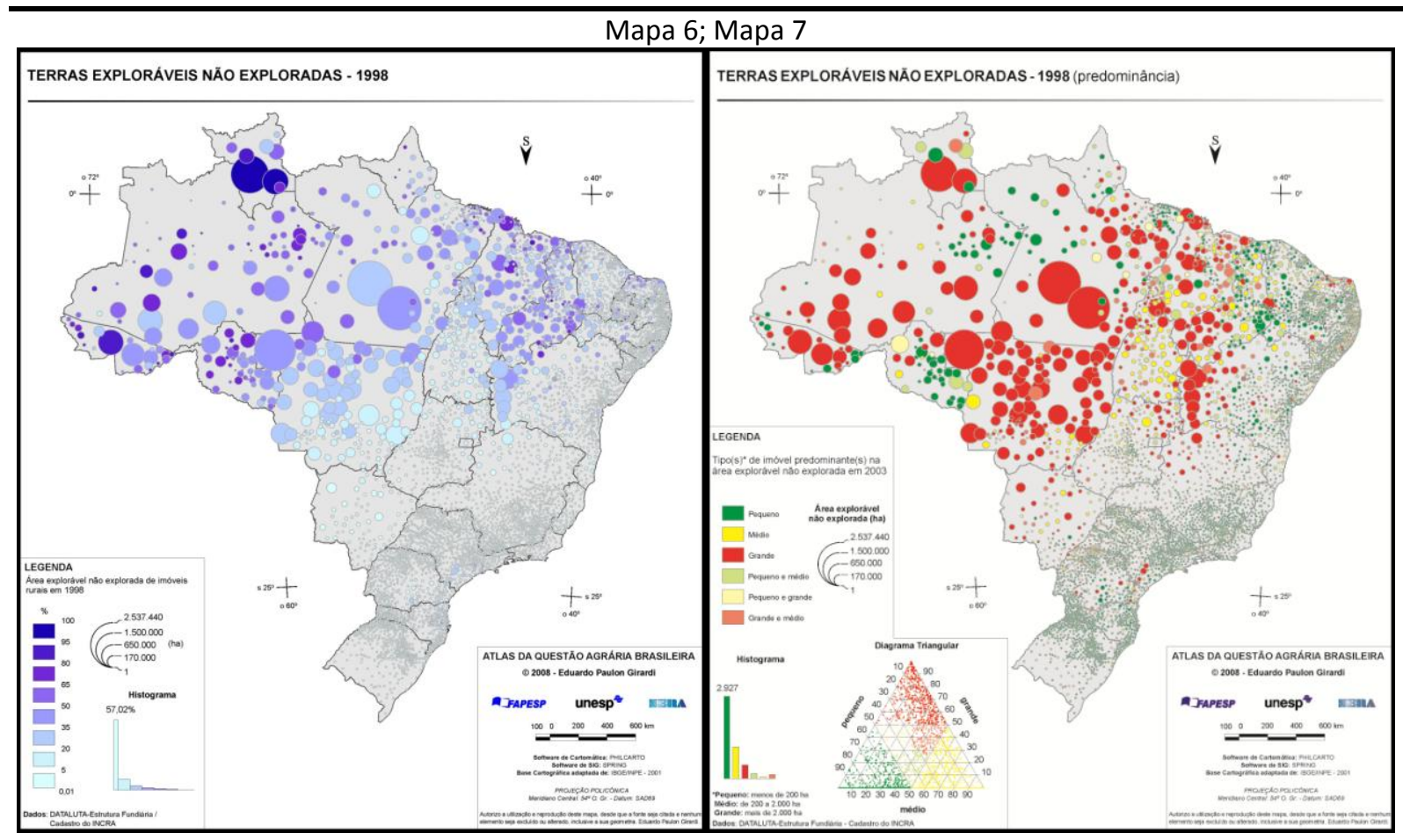

Veja a versão em alta resolução em www.fct.unesp.br/nera/atlas

O mapa8 representa o uso do solo. Nele podemos visualizar uma extensa região central que se estende desde o norte do Paraná até o Maranhão onde são predominantes as áreas de pastagens. Também as pastagens são predominantes no centro de Rondônia, nos Pampas do Rio Grande do Sul e em uma extensa região que compreende Minas Gerais e, de forma geral, o agreste nordestino. As regiões onde predominam as áreas de lavouras estão no norte do Rio Grande do Sul, oeste do Paraná, centro-norte de São Paulo, Zona da Mata nordestina, norte do Ceará e do Maranhão, em alguns municípios do centro de Mato Grosso e no noroeste amazônico, sendo importante dizer que, neste último caso, a área dos estabelecimentos agropecuários é muito pequena em relação às terras públicas. 


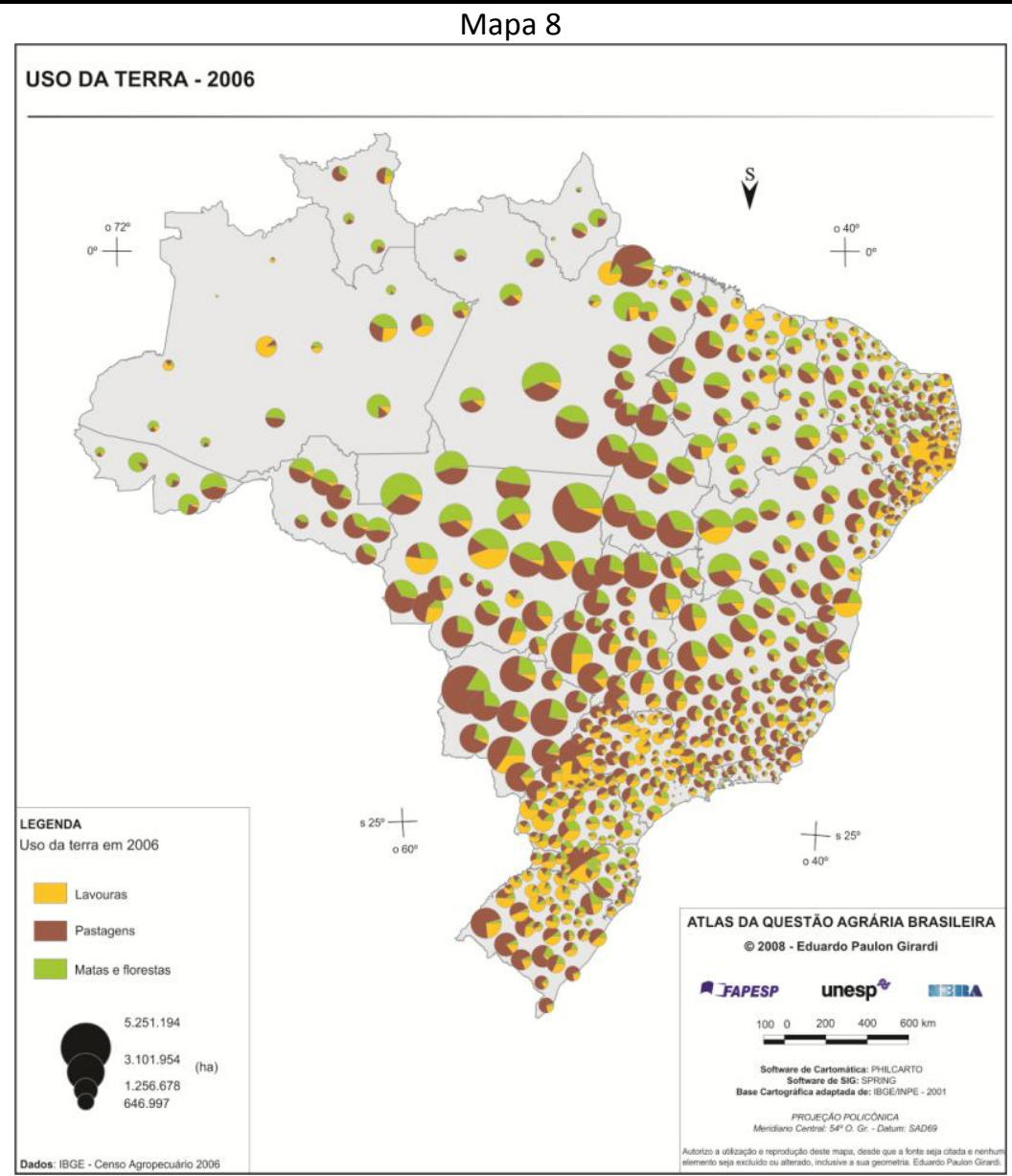

Veja a versão em alta resolução em www.fct.unesp.br/nera/atlas

Estando detalhada a forma de apropriação, concentração/distribuição e uso/desuso da terra regionalmente no Brasil, vejamos o que podemos concluir da dinâmica geral de apropriação de novas terras e o uso das terras no país: em 1998 havia na Amazônia Legal 55,8 milhões de hectares de terras exploráveis não exploradas; segundo os dados do INPE, de 1998 até 2007 foram desflorestados na região 18,9 milhões de hectares (terras inexploráveis que se tornaram exploráveis) e entre 1996 e 2006 a área total de lavouras e de pastagens na Amazônia Legal cresceu 9,4 milhões de hectares, dos quais $56 \%$ relativos às pastagens. Esses três dados nos permitem contradizer todo discurso que mencione a necessidade de desflorestamento na Amazônia (ou em qualquer outra região) para a obtenção de novas terras para a produção agropecuária. Vejamos: se parte dos 55,8 milhões de hectares de terras exploráveis não exploradas da Amazônia Legal verificados em 1998 passassem a ser explorados desde então para a expansão dos 9,4 milhões de hectares de lavouras e pastagens ocorrida na região entre 1996 e 2006, ainda sobrariam, em 2007, cerca de 46,4 milhões de hectares disponíveis para a expansão da agropecuária regional, isso só pelo aproveitamento das terras exploráveis não exploradas de 1998. Contudo, além das terras 
exploráveis não exploradas que havia em 1998, o intenso processo de desflorestamento continua, o que nos permite somar, ao saldo de 46,4 milhões de hectares de terras exploráveis não exploradas, os 18,9 milhões de hectares inutilmente desflorestados na Amazônia entre 1998 e 2007. Com isso, chegamos ao total de 65,3 milhões de hectares de terras exploráveis não exploradas disponíveis em 2007 para a expansão da agropecuária na Amazônia Legal, cuja área total dos imóveis rurais em 2003 era de 177 milhões de hectares e a área total de lavouras e pastagens em 2006 perfazia 67,6 milhões de hectares.

Desta forma, mantendo-se o modelo técnico agrícola atual, a pecuária extremamente extensiva praticada na região e, considerando-se a mesma taxa de crescimento da agropecuária verificada entre 1996 e 2006, que foi de 1,6\% ao ano, os 67,6 milhões de hectares disponíveis seriam suficientes para o crescimento contínuo da agropecuária na Amazônia Legal até 2049 sem que fosse necessário tocar na floresta. É claro que consideramos neste contexto uma situação "ideal", em que não haja nenhum desvio nos dados; não ocorra nenhum progresso técnico na agropecuária neste período e em que a taxa de crescimento da área ocupada pela agropecuária seja constante. O fato é que, apesar de ser um cenário "ideal" e que dificilmente todos os elementos considerados apresentarão a evolução considerada no cálculo, os possíveis desvios de cada um desses três elementos podem ser compensados mutuamente, um pelo outro, de forma que um cenário muito próximo pode se confirmar. A mudança no sistema de pecuária extremamente extensiva pode influenciar profundamente esta evolução, visto que $56,4 \%$ da área adicionada entre 1996 e 2006 são de pastagens, o que corresponde a 5,2 milhões de hectares. Desta forma, cabe aos próximos governos criar alternativas para o desenvolvimento da agropecuária na Amazônia Legal que evitem ocupação de novas áreas por meio do uso adequado das terras úteis já disponíveis, considerando inclusive outros modelos de desenvolvimento agropecuário.

O mapeamento e análise conjunta dos dados da não utilização da terra e das "posses" evidenciam o processo de especulação fundiária na fronteira agropecuária. Isso nos leva a salientar a urgência de repensar a ocupação da Amazônia que, embora tenha perdido destaque, ainda corpota uma fronteira viva. A necessidade de abertura de novas terras na Amazônia é absolutamente infundada, a não ser para a continuação do histórico privilégio do latifúndio. Os únicos objetivos da abertura de novas terras são a exploração de madeira (secundário e cooperativo)masprincipalmente para a apropriação de novas terras por 
grandes posseiros como reserva de valor e para produzir o produto mais lucrativo da fronteira agropecuária - a fazenda. A renda da terra é o objetivo final. A produção de alimentos e/ou produtos agropecuários para o desenvolvimento social e econômico brasileiro não exige a ocupação/privatização/desflorestamento de mais nenhum centímetro quadrado da Amazônia ou outro bioma. Além disso, a grande proporção de terras exploráveis não exploradas em grandes estabelecimentos na Amazônia Legal (mas também no restante do país) indica a consolidação, em um futuro próximo, da parceira latifúndioagronegócio. Esses grandes imóveis serão utilizados para produção do agronegócio assim que as terras forem necessárias. Os grandes imóveis com terras não exploradas são os futuros locus do agronegócio, eis a continuação da histórica aliança latifúndio-capital no campo brasileiro.

\section{CONCLUSÕES}

Consideramos que ampliar os debates sobre a Cartografia Geográfica na Geografia Crítica é um desafio urgente para a Geografia brasileira e uma das razões motivadoras da CGC, assim ressaltamos a necessidade de ampliação e melhoramento da produção cartográfica da Geografia no Brasil.Com a CGC esperamos despertar um debate para repensar o uso que o mapa tem tido na Geografia brasileira - e talvez em "outras geografias" que também tenham se distanciado do mapa. Na CGC apresentamos proposições que acreditamos contribuir para que o mapa seja revalorizado entre os geógrafos; demonstramos alguns elementos que contribuem para o reconhecimento do potencial do mapa para a ampliação das possibilidades de intervenção na realidade através da crítica geográfica. Pretendemos continuar com o desenvolvimento da CGC por meio de releituras, novas leituras, debates com os colegas e pesquisas temáticas na Geografia, em especial na Geografia Agrária.

A CGC não é uma proposta acabada; ela está sendo construída através de práticas e debates. Nossa observação mais recente é de que a Cartografia Social ou Cartografia Participativa, alavancada principalmente pelos antropólogos e desenvolvida junto a grupos de sujeitos excluídos, deve ser compreendida, no contexto da CGC, como uma abordagem cartográfica que permite praticar da forma mais efetiva a crítica cartográfica e talvez seja o elo faltante entre a Geografia Cultural e a cartografia, mas este é tema para um outro artigo. $O$ debate intenso sobre as bases teóricas e instrumentais da Cartografia Geográfica brasileira deve ser 
iniciado para que seja possível estabelecer um destino mais promissor do que aquele previsto atualmente para esta especialidade geográfica.

Por fim, o mapa 8 é a síntese condensada de nossa interpretação da questão agrária brasileira no desenvolvimento do Atlas, estando nele as principais estruturas que consideramos explicativas da questão agrária no contexto do território brasileiro. Todos os elementos da legenda explicativa foram analisados com detalhes no Atlas, cuja íntegra está em www.fct.unesp.br/nera/atlas .

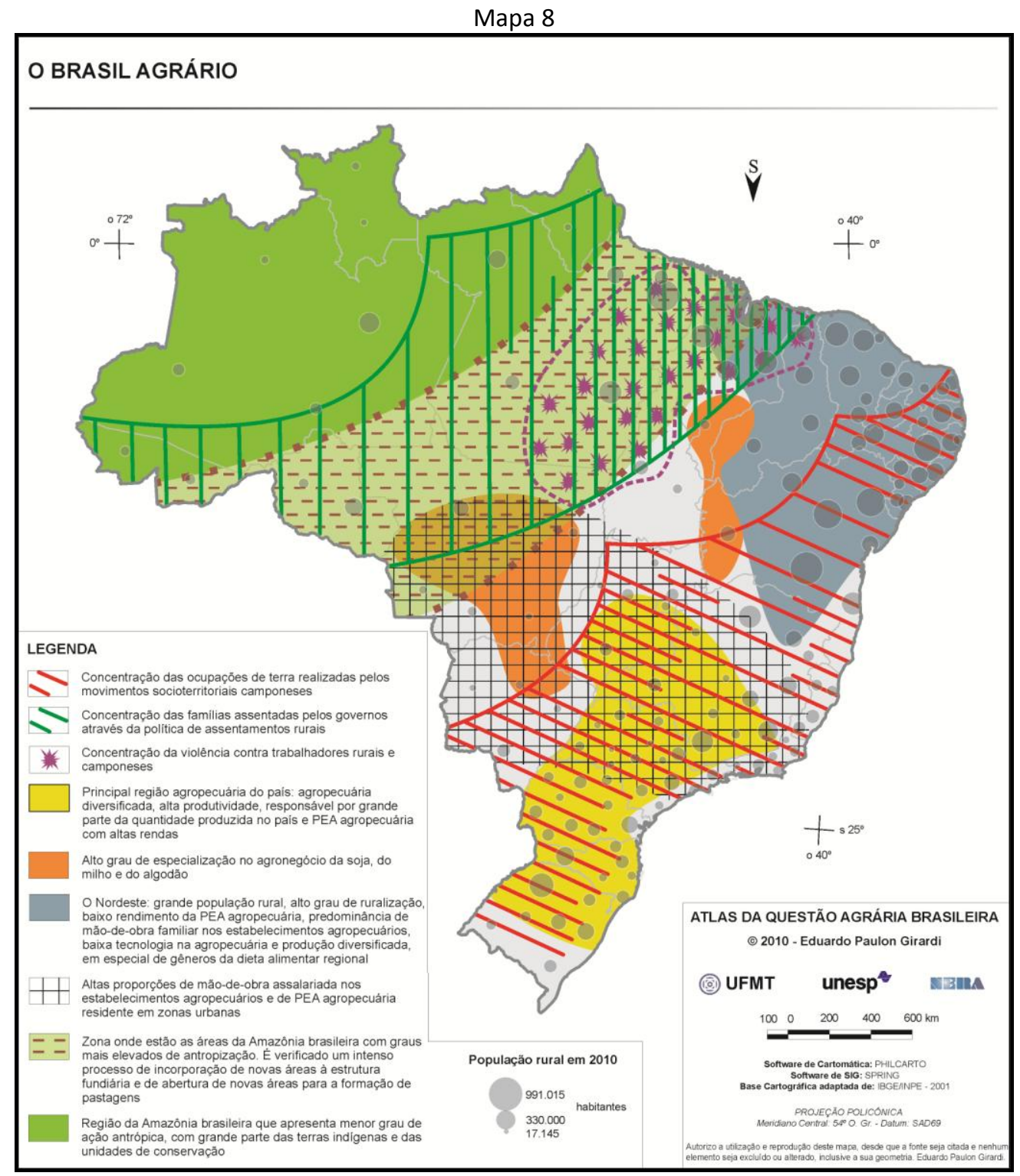

\section{REFERÊNCIAS BIBLIOGRÁFICAS}

BERTIN, J. Sémiologie graphique: les diagrammes, les réseaux, les cartes. Paris: GauthierVillars, 1973 [1962]. 
BLACK, J. Maps and politics. Chicago: The University of Chicago Press, 1997.

BRUNET. Le déchiffrement du monde: théorie et pratique de la géographie. Paris: Belin, $2001[1990]$.

CRAMPTON, J. W.; KRYGIER, J. An introduction to critical cartography. ACME - An International Journal for Critical Geographies. v.04, n.1. Okanagan, 2006. p.12-33.

GIRARDI, E. P. Proposição teórico-metodológica de uma Cartografia Geográfica Crítica e sua aplicação no desenvolvimento do Atlas da Questão Agrária Brasileira. 2008. Tese (Doutorado em Geografia) - Faculdade de Ciências e Tecnologia, Universidade Estadual Paulista, Presidente Prudente, 2008. Discponível em: <www.fct.unesp.br/nera/atlas>.

HARLEY, J. B. Deconstructing the map. Cartographica. v.26, n.2. Toronto: University of Toronto Press, 1989. p.1-20.

IBGE - INSTITUTO BRASILEIRO DE GEOGRAFIA E ESTATÍ́STICA. Censo agropecuário 2006. Rio de Janeiro: IBGE, 2006. Disponível em: <www.ibge.gov.br>.

LACOSTE, Y. A Geografia - isso serve, em primeiro lugar, para fazer a guerra. 7.ed. Campinas: Papirus, 2003 [1985].

MACHEACHREN, A. M.; GANTER, J. H. A pattern identification approach to cartographic visualization. Cartographica. v.27, n.2. Toronto: University of Toronto Press, 1990. p.64-81.

MONMONIER, M. S. How to lie with maps. 2.ed. Chicago: The University of Chicago Press, 1991.

MORAES, A. C. R. e COSTA, W. M. da. Geografia crítica: a valorização do espaço. São Paulo: Hucitec, 1984.

OLIVEIRA, A. U. de. Modo capitalista de produção, agricultura e reforma agrária. São Paulo: FFLCH/Labur Edições, 2007.

PERKINS, C. Cartography - cultures of mapping: power in practice. In: Progress in humanGeography. v.28, n.3, 2004. p.381-391. 
VESENTINI, J. W. A geografia crítica no Brasil: uma interpretação depoente. 2001.

Disponívelem: <www.geocritica.com.br>. 